\title{
SUMBANGSIH UJI PROTEIN TELUR DENGAN MENGGUNAKAN BAWANG PUTIH PADA MATA PELAJARAN BIOLOGI MATERI MAKANAN KELAS XI SMA/MA
}

\author{
Syarifah $^{1}$, Awalul Fatiqin ${ }^{2 *}$, Istiroha ${ }^{2}$ \\ ${ }^{1}$ Dosen Prodi Biologi Fakultas Sains dan Teknologi UIN Raden Fatah Palembang \\ Jl. K. H. Zainal Abidin Fikri No. 1 A KM 3,5 Palembang 30124, Indonesia \\ ${ }^{2}$ Dosen Prodi Pendidikan Biologi Fakultas Ilmu Tarbiyah dan Keguruan UIN Raden Fatah \\ Palembang \\ Jl. K. H. Zainal Abidin Fikri No. 1 A KM 3,5 Palembang 30124, Indonesia \\ ${ }^{3}$ Mahasiswa Prodi Pendidikan Biologi Fakultas Ilmu Tarbiyah dan Keguruan UIN Raden \\ Fatah Palembang
}

Jl. K. H. Zainal Abidin Fikri No. 1 A KM 3,5 Palembang 30124, Indonesia

1*Email: awalulfatiqin_uin@radenfatah.ac.id

\begin{abstract}
Protein compounds containing amino acids, composed of atoms C, H, O and N. Eggs are the source of animal protein that has the highest quality or biological value. The purpose of this study was to determine the value of protein in eggs and application in biology subjects. This research was conducted in June 2016 at IPA Laboratory UIN Raden Fatah Palembang. Protein analysis using Kjedahl method. The result of protein analysis obtained was lowest with the addition of garlic P3 (200 g) the average value of 9.25\%, the addition of garlic P2 (150 g) and P1 (100 g) with the mean of $9.42 \%$ and $9.48 \%$ had the same result systematically. Contribution in biology subjects is given in the method of egg protein test work with the addition of garlic in a systematic manner. In this case it can be concluded Fcount> Ftabel, so the addition of garlic is able to maintain the quality of protein in eggs awake and its contribution in the biology lesson of food in the form LKS.
\end{abstract}

Keywords: Protein; Egg; Garlic; Biology; Food.

\section{PENDAHULUAN}

Sub materi makanan di kelas XI SMA/MA membahas tentang zat gizi dan fungsinya bagi manusia. Salah satu indikator yang terdapat di dalam silabus pada sub materi ini adalah: menentukan kandungan gizi yang terdapat dalam makanan dan mengidentifikasi zat yang terdapat di dalam makanan dan fungsinya bagi tubuh. Menurut Soedibyo (1998), salah satu tanaman yang dapat menjaga kadar protein adalah bawang putih. Bawang putih mempunyai kandungan yaitu saponin, dan flavonoid yang berfungi sebagai anti bakteri. Bawang putih merupakan tanaman berkhasiat sebagai obat untuk penyakit batuk, cacingan, tekanan darah, menghambat penuaan, maag, dan diabetes. Senyawa yang terkandung didalam bawang putih yaitu alisin. Alisin adalah zat yang memberikan bau yang khas, mempunyai daya antibiotik, antibakteri, serta berkhasiat menurunkan kolesterol dan tekanan darah tinggi (Sarasvati, 2008).

Telur ayam kampung, adalah salah satu bahan makanan yang dihasilkan dari ternak ayam kampung, berbentuk bulat sampai lonjong dengan berat yang relatif lebih kecil dari telur ayam negeri yaitu sekitar 36-37 gram per butirnya dengan warna cangkang berwarna putih (Sudaryani, 2000). Meskipun telur ayam kampung berukuran lebih kecil, warna kulitnya lebih putih dan harganya lebih mahal dari telur ayam negeri, namun telur ayam kampung lebih diminati oleh masyakarat dari pada telur ayam negeri. Telur ayam kampung 
dikonsumsi masyarakat sebagai bahan makanan yang mempunyai nilai gizi tinggi karena banyak mengandug zat-zat yang dibutuhkan oleh tubuh diantaranya protein yang lengkap dengan asam amino, lemak, vitamin, dan mineral dengan daya cerna yang tinggi (Sudaryani, 2000).

Bawang putih mengandung lebih dari 200 senyawa kimia. Beberapa diantaranya sangat penting, salah satunya termasuk: volatile oil $(0,1-0,36 \%)$ yang mengandung sulfur, termasuk didalamnya adalah alliin, ajoene dan vinyldithiines (produk sampingan alliin yang dihasilkan secara non enzimatik dari allicin), $S$ allylmercaptocysteine (ASSC) dan $S$ methylmercaptocysteine (MSSC), terpenes (citral, geraniol, linalool, $\alpha$-phellandrene, dan $\beta$-phellandrene). Allicin (diallyl thiosulphinate) yang diproduksi secara enzimatik dari alliin, berperan sebagai antibiotik. Ajoene berperan sebagai anti koagulan dari bawang putih. Bawang putih juga mengadung enzim allinase, peroxidase dan myrosinase, serta bahan lain seperti protein, mineral, vitamin, lemak, asam amino dan prostaglandin (Newall et al., 1996).

Andrianto (2013), menganalisis kandungan albumin dan organoleptik telur ayam leghorn setalah penambahan ekstrak bawang putih (Allium sativum) dengan kosentrasi berbeda, pemberian ekstrak bawang putih dengan kosentrasi berbeda mempengaruhi organoleptik dan kandungan protein albumin ayam leghorn. Sidiq (2014), Uji kadar protein dan organoleptik pada telur ayam leghorn setelah disuntik ekstrak Black garlic menunjukkan penambahan ekstrak bawang putih mempengaruhi kadar protein dan organoleptik pada telur. Dari penelitian ini menganalisis kandungan protein pada telur agar tetap terjaga dengan menggunakan bawang putih untung memperoleh nilai protein dan kadar organoleptiknya terjaga. Khususnya peningkatan materi pada pelajaran biologi.

\section{METODOLOGI PENELITIAN}

Penelitian ini akan dilaksanakan pada bulan juni 2016 di Laboratorium MIPA Uin Raden Fatah Palembang dan Laboratorium Kimia Terapan Politeknik
Kesehatan Jurusan Analisis Kota Palembang. Penelitian ini menggunakan metode eksperimen kuantitatif. Penelitian ini meliputi sampel berupa telur ayam kampung dan serutan bawang putih yang dibeli di pasar km. 5 Palembang.

\section{Analisis Protein Telur}

Menurut Sudarmadji, dkk (2007), analisis kadar protein ada bebarapa tahap, yaitu:

\section{a. Tahap destruksi}

1. Pada tahap ini pertama-tama sampel dipanaskan dalam asam sulfat pekat

2. Selanjutnya tambahkan katalisator berupa campuran $\mathrm{Na}_{2} \mathrm{SO}_{4}$, untuk mempercepat proses destruksi

3. Hasil dari destruksi ditampung dalam labu kjedhal, yang akan digunakan untuk tahap destilasi.

\section{b. Tahap destilasi}

1. Pada tahap destilasi, tambahkan $\mathrm{NaOH}$ untuk memecah ammonium sulfat menjadi ammonia $\left(\mathrm{NH}_{3}\right)$ sampai kalis dan panaskan.

2. Hasil dari destilasi selanjutnya ditampung dalam penampung destilan (Lampiran 8 hal. 69).

\section{c. Tahap titrasi}

1. Pada tahap ini asam khorida yang bereaksi dengan ammonia $\left(\mathrm{NH}_{3}\right)$ yang ditampung didestilan di titrasi dengan $\mathrm{NaOH} 0,1 \mathrm{~N}$.

2. Selanjutnya pada tahap akhir titrasi di tandai dengan perubahan warna larutan menjadi merah muda

3. Kemudian gunakan indikator PP (Phenolflafain) untuk melihat perubahan warna tersebut (Lampiran 3 hal. 46 dan lampiran 8 hal. 70)

4. Dan hitung kadar proteinnya dengan mengalihkan suatu faktor

\section{Sumbangsih Pada Pelajaran Biologi}

Sumbangsih pembelajaran di sekolah khususnya pada kelas XI SMA/MA semester genap pada materi zat-zat makanan untuk pembaharuan pembelajaran baik teori di kelas maupun kegiatan praktikum siswa dengan metode eksperimen, untuk mencapai kegiatan pembelajaran, diberikan contoh perangkat 
pembelajaran yaitu Lembar kerja siswa (LKS).

\section{HASIL DAN PEMBAHASAN}

\section{A. Hasil}

Hasil penelitian sumbangsih analisis uji protein telur dengan menggunakan bawang putih pada pelajaran biologi materi makanan kelas XI SMA/MA sebagai berikut:

\section{Analisis Protein Telur}

Tabel 1 Hasil Kadar Protein Putih Telur Ayam Kampung

\begin{tabular}{|c|c|c|c|c|c|}
\hline \multirow[t]{2}{*}{ Perlakuan (t) } & \multicolumn{3}{|c|}{ Ulangan (r) (\%) } & \multirow{2}{*}{$\begin{array}{c}\text { Jumlah } \\
\text { (TA) }\end{array}$} & \multirow[t]{2}{*}{ Rerata } \\
\hline & 1 & 2 & 3 & & \\
\hline P0 (Kontrol) & 9,47 & 9,66 & 9,73 & 28,86 & 9,62 \\
\hline P1 (100 gram) & 9,42 & 9,50 & 9,53 & 28,45 & 9,48 \\
\hline P2 (150 gram) & 9,35 & 9,42 & 9.50 & 28,27 & 9,42 \\
\hline P3 (200 gram) & 9,32 & 9,27 & 9,18 & 27,77 & 9,25 \\
\hline Jumlah (TU) & 37,56 & $\mathbf{3 7 , 8 5}$ & 37,94 & 113,35 & 37,77 \\
\hline
\end{tabular}

Berdasarkan hasil yang diperoleh, kali ulangan. Adapun hasil analisis tersebut kemudian dilakukan analisis of varians adalah sebagai berikut: dengan pola RAL dengan 4 perlakuan dan 3

Tabel 2 Analisis Sidik Ragam Kadar Protein Putih Telur Ayam Kampung

\begin{tabular}{|c|c|c|c|c|c|}
\hline SK & DB & JK & KT & F hittung & $\mathbf{F}_{\text {tabel 5\% }}$ \\
\hline Perlakuan & 3 & 0,204 & 0,068 & $8,5^{* *}$ & 4,07 \\
\hline Galat & 8 & 0,064 & 0,008 & & \\
\hline Total & 11 & 0,268 & & & \\
\hline
\end{tabular}

Berdasarkan hasil analisis data tabel 2 diketahui bahwa $F_{\text {hitung }}>\mathrm{F}_{\text {tabel }}$ hal ini menyatakan bahwa pengaruh pemberian bawang putih pada telur ayam kampung memberikan pengaruh nyata terhadap kadar protein telur ayam kampung. Selanjutnya untuk mengetahui perbedaan pengaruh masing-masing perlakuan dilakukan uji lanjut menggunakan Uji Beda Nyata Jujur (BNJ) pada taraf $5 \%$ seperti pada tabel 3 berikut:

Tabel 3 Uji Beda Nyata Jujur (BNJ) Pengaruh Bawang Putih Terhadap Kadar Protein Telur Ayam Kampung

\begin{tabular}{|c|c|c|c|c|c|}
\hline \multirow[t]{2}{*}{ Perlakuan } & \multirow[t]{2}{*}{ Rataan } & \multicolumn{3}{|c|}{ Beda dengan } & BNJ \\
\hline & & $\mathrm{P}_{2}$ & $\mathrm{P}_{1}$ & $\mathrm{P}_{0}$ & 0.05 \\
\hline $\mathrm{P}_{0}$ & 9,62 & $0,37 * *$ & 0,2 & 0,14 & B \\
\hline $\mathrm{P}_{1}$ & 9,48 & $0,23 *$ & 0,06 & _- & B \\
\hline $\mathrm{P}_{2}$ & 9,42 & 0,17 & - & & $\mathrm{Ab}$ \\
\hline $\mathrm{P}_{3}$ & 9,25 & & & & A \\
\hline$Q_{0.05}(p, 8)$ & & 4,04 & & & \\
\hline $\mathbf{Q}_{0.01}(\mathrm{p} .8)$ & & 5,63 & & & \\
\hline$\omega=Q_{0,05}(p .8) . S \bar{y}$ & & 0,22 & & & \\
\hline$\omega=Q_{0,01}(p .8) . S \bar{y}$ & & 0,29 & & & \\
\hline
\end{tabular}


2. Sumbangsih Pada Mata Pelajaran Biologi

Lembar Kerja Siswa sebagai berikut:

Judul : Struktur dan fungsi organ, penyakit atau kelainan pada sistem pencernaan

Standar kompetensi : Menjelaskan struktur dan fungsi organ manusia dan hewan tertentu, kelainan/penyakit yang mungkin terjadi serta implikasinya

Salingtemas

Kompetensi dasar : Menjelaskan keterkaitan struktur, fungsi, dan proses kelainan penyakit yang dapat terjadi pada sistem pencernaan makanan pada manusia dan hewan (misalnya ruminansial).

Indikator :

1. Menentukan kandungan gizi yang terdapat dalam bahan makanan dengan menggunakan telur.

2. Mengidentifikasi zat-zat yang terdapat dalam bahan makanan dan fungsinya bagi tubuh

\section{Nama percobaan : Analisis Protein}

Tujuan : Untuk mengetahui pengaruh bawang putih (Allium sativum) terhadap kadar protein telur?

\section{Alat dan Bahan}

Alat

Alat yang digunakan dalam penelitian ini meliputi Neraca analitik, Toples,

parutan, pengaduk, pisau, gelas ukur, alat tulis, labu kjedhal, Erlenmeyer, pipet tetes, lampu bunsen, tabung reaksi, pengaduk kaca, alat destilasi, alat titrasi, neraca teknik analitik.

\section{Bahan}

Bahan yang digunakan dalam penelitian ini adalah telur ayam kampung sebanyak 24 butir, bawang putih, aquades, $\mathrm{H}_{2} \mathrm{SO}_{4}$ pekat (Asam Sulfat), serbuk $\mathrm{CuSO}_{4}, \mathrm{NaOH} 0,1 \mathrm{~N}$ (Natrium Hidrosida), $\mathrm{HCl} 0,1 \mathrm{~N}, \mathrm{Na}_{2} \mathrm{SO}_{4}$ (Anhidrat), $\mathrm{NaOH}$ 45\%, PP 1\%, alcohol.

\section{Petunjuk Pengerjaan:}

1. Kerjakan LKS dengan tepat!

2. Ikuti petunjuk yang disediakan dengan cermat!

3. Tuliskan laporan dan kesimpulan kegiatan ini, kemudian kumpulkan kepada guru.

\section{Materi}

Makanan yang bergizi adalah makanan yang mengandung zat pengatur, pembangun, dan sumber energi. Oleh karena itu, sumber makanan harus selalu tersedia pada setiap saat. Makanan harus selalu terjaga kualitasnya agar tetap baik. Untuk mengetahui bahan makanan bergizi atau tidak perlu pengujian. (Dyah Sushmita, 2012).

Bawang putih termasuk klasifikasi tumbuhan berumbi lapis atau siung yang bersusun. Bawang putih tumbuh secara berumpun dan berdiri tegak sampai setinggi $30-75 \mathrm{~cm}$, mempunyai batang semu yang terbentuk dari pelepah-pelepah daun. Helaian daunnya mirip pita, berbentuk pipih dan memanjang. Akar bawang putih terdiri dari serabut-serabut kecil yang bejumlah banyak. Setiap umbi bawang putih terdiri dari sejumlah anak bawang (siung) yang setiap siungnya terbungkus kulit tipis berwarna putih (Linn, 2009). Bau khas pada bawang akan timbul bila jaringan tanaman tersebut terluka, karena prekursor bau dan cita rasa terletak pada bagian sitoplasma.

Telur merupakan produk peternakan yang mengandung asam amino esensial yang dibutuhkan tubuh manusia. Berdasarkan kandungan gizinya telur dapat dikategorikan sebagai makanan bergizi tinggi. Telur merupakan salah satu sumber protein hewani disamping daging ikan dan susu yang baik dikonsumsi oleh manusia, baik anak-anak pada masa pertumbuhan, ibu hamil dan menyusui, serta mereka yang sedang dalam proses penyembuhan. Selain itu telur juga mengandung vitamin $\mathrm{A}$ dan $\mathrm{B}$, lemak serta mineral (Suprapti, 2005).

\section{Langkah-langkah:}

1. Persiapan Alat dan Bahan

a. Siapkan alat dan bahan yang akan digunakan untuk penelitian. 
b. Cari dan tinjau tempat penjualan alat dan bahan yang diperlukan untuk penelitian.

c. Selanjutnya rancang dosis bawang putih yang akan digunakan sebagai perlakuan.

d. Lalu cuci toples yang akan digunakan.

e. Kemudian atur letak toples yang akan digunakan sesuai parameter.

f. Siapakan kertas label yang bertuliskan rancangan perlakuan dan ulangan dengan spidol permanen agar tidak tertukar.

Tempelkan label pada toples yang akan digunakan dan tutup label dengan lakban bening agar tidak basah.

2. Pembuatan bawang putih sebagai campuran dalam pemeraman telur ayam kampung

a. Pertama-tama kupas kulit bawang putih dengan pisau kemudian dicuci bersih dengan air.

b. Kemudian bawang putih diparut dengan menggunakan alat parut. Berat bawang putih yang digunakan adalah 100 gr, 150 gr, dan 200 gr.

c. Selanjutnya telur ayam kampung dibersihkan cangkangnya dengan air hangat.

d. Lalu telur ayam kampung dibalut dengan bawang putih dan dimasukkan atau diperam kedalam toples

e. Untuk pemeraman, 3 toples tidak diberi bawang putih, sedangkan 9 toples diberi bawang putih dengan ukuran yang berbeda-beda yaitu Sebanyak 100 gr, 150 gr dan 200 gr

f. Selanjutnya dilakukan pemeraman selama 14 hari

g. Setelah 14 hari telur ayam kampung di angkat, lalu dibersihkan dan dicuci dengan air.

h. Kemudian direbus selama 10-11 menit.

i. Setelah itu dilakukan uji protein pada telur tersebut.

3. Analisis Kadar Protein

Menurut Sudarmadji, dkk (2007), analisis kadar protein ada bebarapa tahap, yaitu:

a. Tahap destruksi
1. Pada tahap ini pertama-tama sampel dipanaskan dalam asam sulfat pekat

2. Selanjutnya tambahkan katalisator berupa campuran $\mathrm{Na}_{2} \mathrm{SO}_{4}$, untuk mempercepat proses destruksi

3. Hasil dari destruksi ditampung dalam labu kjedhal, yang akan digunakan untuk tahap destilasi.

b. Tahap destilasi

1. Pada tahap destilasi, tambahkan $\mathrm{NaOH}$ untuk memecah ammonium sulfat menjadi ammonia $\left(\mathrm{NH}_{3}\right)$ sampai kalis dan panaskan.

2. Hasil dari destilasi selanjutnya ditampung dalam penampung destilan.

c. Tahap titrasi

1. Pada tahap ini asam khorida yang bereaksi dengan ammonia $\left(\mathrm{NH}_{3}\right)$ yang ditampung didestilan di titrasi dengan $\mathrm{NaOH} 0,1 \mathrm{~N}$.

2. Selanjutnya pada tahap akhir titrasi di tandai dengan perubahan warna larutan menjadi merah muda

3. Kemudian gunakan indikator PP (Phenolflafain) untuk melihat perubahan warna tersebut.

4. Dan hitung kadar proteinnya dengan mengalihkan suatu faktor

\section{Pertanyaan Diskusi}

1. Berdasarkan hasil pengamatan, apakah ada pengaruh pemberian bawang putih pada protein telur dengan kadar yang berbeda-beda?

2. Kesimpulan apakah yang dapat diperoleh dari kegiatan praktikum ini.

\section{B. Pembahasan}

Berdasarkan Tabel 1 dapat diketahui bahwa perlakuan berpengaruh sangat nyata. Dari data yang di dapat, perlakuan $\mathrm{P}_{3}$ dengan penambahan bawang putih seberat 200 gram memiliki kadar protein yang paling rendah dengan rata-rata sebesar 9,25 gram. Rendahnya kadar protein pada perlakuan $\mathrm{P}_{3}$ dengan penambahan bawang putih seberat 200 gram disebabkan karena protein pada telur ayam kampung mengalami denaturasi atau terjadi perubahan struktur protein setelah penambahan bawang putih. Menurut Zulfikar "dalam" Ayuz (2008), denaturasi protein merupakan suatu keadaan dimana 
protein mengalami perubahan atau perusakan struktur sekunder dan tersier. Sedangkan faktor yang dapat menyebabkan terjadinya denaturasi protein diantaranya pemanasan, suasana asam basa.

Kemudian, untuk perlakuan $\mathrm{P}_{2}$ dengan penambahan bawang putih seberat 150 gram dan perlakuan $\mathrm{P}_{1}$ dengan penambahan bawang putih seberat 100 gram memiliki rata-rata sebesar 9,42 gram dan 9,48 gram. Pada perlakuan $\mathrm{P}_{2}$ (150 gram) dan $\mathrm{P}_{1}$ (100 gram) mempunyai hasil yang sama secara statistik, hal ini disebabkan karena penambahan bawang putih pada kadar tersebut telah terjadi koagulasi yang sempurna sehingga kadar protein telur ayam kampung tidak berpengaruh. Ditambahkan oleh Zulfikar “dalam”Ayuza (2008), penambahan bawang putih dapat menyebabkan pumutusan ikatan hidrogen yang menompang struktur sekunder dan tersier suatu protein sehingga menyebabkan sisi hidrofobik dari gugus samping polipetida terbuka.

Selain itu, senyawa tanin yang terkandung dalam bawang putih menghambat proteolitik yang berperan menguraikan protein menjadi asam amino dan senyawa allicin yang terkandung dalam bawang putih juga dapat merusak dinding sel dan menghambat sintesis protein. Minyak atsiri pada bawang putih diduga memiliki kemampuan anti oksidan, yang artinya minyak atsiri dari bawang putih dapat menurunkan radikal bebas yang menyebabkan penurunan kadar protein pada telur. Menurut penelitian Riko Andrianto tahun 2013, menunjukkan bahwa penambahan ekstrak bawang putih (Allium sativum) dapat menurunkan kadar protein pada telur ayam leghorn. Penurunan kadar protein terbesar terjadi pada penambahan ekstrak bawang putih sebesar 1,5 mL/ 1 butir telur ayam. Sedangkan kadar protein telur ayam kampung yang paling tinggi adalah telur ayam kampung yang tidak diberi bawang putih $\mathrm{P}_{0}$ (kontrol) dengan rata-rata sebesar 9,62 g.

Menurut penelitian yang telah dilakukan menunjukkan bahwa pemberian bawang putih 0 gram (0\%) ke 200 gram (3,6 $\%)$ pada telur ayam kampung dapat menurunkan kadar protein 9,62 g $(0,17 \%)$ ke 9,25 g (0,16\%) atau sebesar 0,01\%, hal ini disebabkan karena bawang putih masuk dari celah-celah cangkang telur sehingga menyebabkan sedikit penurunan pada kadar protein telur ayam kampung. Ditambahkan oleh Patria $d k k$ (2015), menunjukkan bahwa penambahan ekstrak bawang putih $0 \%$ ke 20 $\%$ pada daging ayam dapat menurunkan kadar protein $20,43 \%$ menjadi $19,89 \%$.

Selanjutnya untuk mengetahui perbedaan pengaruh masing-masing perlakuan dilakukan uji lanjut menggunakan uji beda nyata jujur (BNJ) pada taraf $5 \%$. Dari uji Beda Nyata Jujur (BNJ) dapat disimpulkan bahwa perlakuan $\mathrm{P}_{3}$ tidak berbeda nyata dengan perlakuan $\mathrm{P}_{2}$, kemudian perlakuan $\mathrm{P}_{3}$ berbeda nyata dengan perlakuan $P_{1}$, selanjutnya perlakuan $\mathrm{P}_{2}$ berbeda nyata dengan perlakuan $\mathrm{P}_{1}$, lalu perlakuan $\mathrm{P}_{3}$ berbeda sangat nyata dengan perlakuan $\mathrm{P} 0$ dan perlakuan $\mathrm{P}_{2}$ berbeda sangat nyata dengan perlakuan $\mathrm{P}_{0}$, dalam hal ini bearti Ho pada penelitian ini diterima pada taraf uji 5\% karena pengaruh kedua perlakuan yang dibandingkan tidak berbeda nyata atau bisa dikatakan bahwa rataan antar perlakuan < dari nilai BNJ 0,05.

Keberhasilan seorang guru dalam menyampaikan pembelajaran merupakan sesuatu yang diharapkan sehingga untuk memenuhi tujuan tersebut diperlukan sesuatu yang matang. Sukardi (2013) menyatakan bahwa pembelajaran adalah suatu kegiatan pendidikan yang mewarnai interaksi yang terjadi antara guru dengan anak didik. Dalam interaksi ini guru dengan sadar merencanakan kegiatan mengajarnya secara sistematis dengan memanfaatkan segala sumber yang ada.

Setiap makhluk hidup membutuhkan makanan. Tanpa makanan, makhluk hidup akan sulit dalam mengerjakan aktivitas sehari-harinya. Makanan dapat membantu kita dalam mendapatkan energi, membantu pertumbuhan badan dan otak. Memakan makanan yang bergizi akan membantu pertumbuhan kita, baik otak maupun badan. Setiap makanan mempunyai kandungan gizi yang berbeda. Protein, karbohidrat, lemak, dan lain-lain adalah salah satu contoh gizi yang akan kita dapatkan dari makanan.

Makanan yang bergizi adalah makanan yang mengandung zat pengatur, 
pembangun, dan sumber energi. Oleh karena itu, sumber makanan harus selalu tersedia pada setiap saat. Makanan harus selalu terjaga kualitasnya agar tetap baik. Untuk mengetahui bahan makanan bergizi atau tidak perlu pengujian.

Penelitian berjudul "Pengaruh Bawang Putih (Allium sativum) Terhadap Kadar Protein Telur Ayam Kampung dan Sumbangsihnya Pada Mata Pelajaran Biologi Materi Makanan Kelas XI SMA/MA." Ini akan di sumbangsihkan pada kegunaan pembelajaran di sekolah khususnya pada kelas XI SMA/MA semester genap pada materi zat-zat makanan untuk pembaharuan pembelajaran baik teori di kelas maupun kegiatan praktikum siswa dengan metode eksperimen, untuk mencapai kegiatan pembelajaran, diberikan contoh perangkat pembelajaran yaitu Rencana Pelaksanaan Pembelajaran RPP dan LKS

\section{KESIMPULAN}

1. Bawang putih berpengaruh sangat nyata terhadap penurunan kadar protein telur ayam kampung dan $F_{\text {hitung }}>\mathrm{F}_{\text {tabel }}$ dengan rata-rata 9,25 pada perlakuan $\left(\mathrm{P}_{3}\right)$ dengan kadar 200 gram.

2. Sumbangsih dari penelitian ini berupa Rpp Praktikum Analisis Kadar
Protein dan LKS Materi Makanan (Protein).

\section{DAFTAR PUSTAKA}

[1] Newall, C.A., Anderson, L.A., Phillipson, J.D., 1996. Herbal Medicines, A Guide for Health-care Professionals. London: The Pharmaceutical Press.

[2] Prawirohartono, EP. 2001. Makanan sebagai Penyebab Alergi dalam Alergi Makanan. Yogyakarta: Gajah Mada Universitas Press.

[3] Sarasvati. 2008. Rainbow Diet 60 Resep Sajian Warna-Warni Lezat Dan Sarat Khasiat. Jakarta: PT Gramedia Pustaka.

[4] Soedibyo, M. 1998. Alam Sumber Kesehatan Manfaat dan Kegunaan. Balai Pustaka. Jakarta.

[5] Sudarmadji, S. 2007. Analisis Bahan Makanan Dan Pertanian. Yogyakarta: Universitas Gajah Mada

[6] Sudaryani, T. 2000. Kualitas Telur. Jakarta : Penebar Swadaya.

[7] Supraptini, M.S. 1985. "Pengkajian Sifat-Sifat Produksi Ayam Kampung serta Persilangannya dengan Rhode Island Red" (Disertasi) Bogor : Institut Pertanian Bogor.

[8] Warsito, A. 1996. Biokimia. Surakarta: FKIP UMS 